\title{
LED による特定周波数の光刺激がレタスの生育に及ぼす影響
}

\author{
中林和重・鈴木崇範 \\ 明治大学農学部 214-8571 神奈川県川崎市多摩区東三田 1-1-1
}

Effect of LED-light Stimulation at Specific Frequencies on Lettuce Growth

\author{
Kazushige NAKABAYASHI and Takanori SuzUKI \\ Department of Agricultural Chemistry, Faculty of Agriculture, Meiji University, 1-1-1 \\ Higashimita, Tama, Kawasaki, 214-8571, Japan
}

\begin{abstract}
Plant growth rate can be controlled by adjusting both the light quality and during light and dark transition. Light intensity and time also have an effect on growth rate.

We investigated the effects of low-intensity light irradiation of specific frequency on the growth and inorganic contents of lettuce in the field. Lettuce was cultivated using three types of nutrient solution (complete nutrition, $\mathrm{NO}_{3}-\mathrm{N}$-excessive, $\mathrm{NO}_{3}-\mathrm{N}$-deficient). Light sources were red and yellow LEDs, which are low-cost artificial light sources used in plant production. Leaves were irradiated by pulsed LED-light for several hours each day.

Red and yellow LED-light stimulation of specific frequency $(20 \mathrm{~Hz}, 50 \mathrm{~Hz})$ increased the lettuce yield in nutrient solutions with lower $\mathrm{NO}_{3}-\mathrm{N}$ concentrations, despite of the fact that the chlorophyll in lettuce does not response much yellow light. Changes in light stimulation frequency affected $\mathrm{NO}_{3}-\mathrm{N}$ concentrations in lettuce sap. These results suggest that stimulation by red or yellow LED-light in the field has a positive effect on photosynthetic activity.
\end{abstract}

Keywords : culuture, hydroponic, LED, light stimulation, photosynthetic activity

緒言

植物へ人工光を照射する研究が盛んに進められており， 光の質や明暗周期を制御することにより，植物の生育を 制御できることが知られている ${ }^{1 \sim 5)}$.われわれも野外で 生育しているレタスやトマトに, $20 \mathrm{~Hz}$ のストロボ光を 照射すると，生育や無機成分濃度が変化することを見出 している ${ }^{6 \sim 8)}$. 本研究ではガラス温室内で生育している レタスに, 種々の周波数で点滅している LED 光を照射 した結果, 生育や汁液無機成分濃度に変化が見られたの で報告する。

2002 年 10 月 7 日受付

2003 年 6 月 3 日受理

Corresponding author: Kazushige Nakabayashi (planfood@kw.netlaputa.ne.jp)
材料および方法

\section{1. 試 験 区}

試験区は実験計画法礼に基づいて，くり返しのある多 因子多水準試験 ${ }^{10)}$ とした。すなわち，培養液の硝酸態窒 素濃度の違いの因子について 3 水準(標準濃度, 標準濃 度の \pm 3 割濃度), 光色の違いの因子について 2 水準 (赤 色光, 黄色光), 光の点滅周波数の違いの因子について 4 水準 $(20 \mathrm{~Hz}, 50 \mathrm{~Hz}, 2500 \mathrm{~Hz}$ ，連続光）を組み合わせた 24 通りを 2 反復して 48 試験区を設けた。また，対象区 として培養液の窒素濃度の違い 3 水準について，それぞ れ無照射区を設けた。

\section{2. 栽培 概 要}

栽培は明治大学生田校舎 (神奈川県川崎市) 圃場内のガ

ラス温室内で行った。供試作物はレタス (Lactuca sativa L. 品種 ‘しずか’：横浜植木株式会社）を用い，2001 年 
10 月 22 日にバーミキュライト床に播種し, 子葉展開後 ウレタン製スポンジに仮植した. 11 月 16 日(播種後 25 日目)に試験区ごとに定めた培養液 61 を満たしたプラス チック製の栽培ベッド $(54 \times 34 \times 9(\mathrm{~cm}))$ に，定植床に見 立てた発泡スチロール板を浮かべ, 各試験区とも 6 株ず つ定植した. その後 12 月 7 日 (播種後 47 日目)よりの光 点滅照射を開始し, 12 月 25 日(播種後 65 日目)に栽培 を終了して, 生育調查および化学分析を行った。

培養液は, 仮植までは園芸試験場処方の 0.3 単位, 定 植までは 0.5 単位で管理した。定植後は硝酸態窒素標準 濃度区では山崎レタス処方 ${ }^{11)}$ を用い, 硝酸態窒素高濃度 区では硝酸態窒素濃度を標準区の 3 割増, 硝酸態窒素低 濃度区では標準区の 3 割減とした (Table 1).

光源には, 赤色 $\operatorname{LED}(\mathrm{ER}-500 \mathrm{~L}$ ：スタンレー電気， 5 $\mathrm{mm}$ 径, $7.6 \mathrm{~mm}$ 長, 最大発光波長 $660 \mathrm{~nm}$ ) と黄色 LED (HPY5066X : スタンレー電気, $5 \mathrm{~mm}$ 径, $7.6 \mathrm{~mm}$ 長, 最大発光波長 $570 \mathrm{~nm}$ ) をレタス 1 株につき 1 個ずつ設置

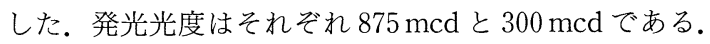
LED は植物体上方に張った細い針金 $(2 \mathrm{~mm}$ 径)に取り 付けた (Fig. 1). 照射時間は毎日 AM9：00〜 11：00の 2 時間とし, デューティー比は $1: 1$ とした.なお LED から定植床までの距離は約 $15 \mathrm{~cm}$ であり, 植物体上部

Table 1 Composition of nutrient solutions

\begin{tabular}{clllll}
\hline \hline $\begin{array}{c}\mathrm{NO}_{3}-\mathrm{N} \\
\text { concentration }\end{array}$ & $\mathrm{N}$ & $\mathrm{P}$ & $\mathrm{K}$ & $\mathrm{Ca}$ & $\mathrm{Mg}$ \\
\hline High & 7.8 & & & & \\
\cline { 1 - 2 } Standard & 6 & 1.5 & 4 & 2 & 1 \\
\hline Low & 4.2 & & & & \\
\hline
\end{tabular}

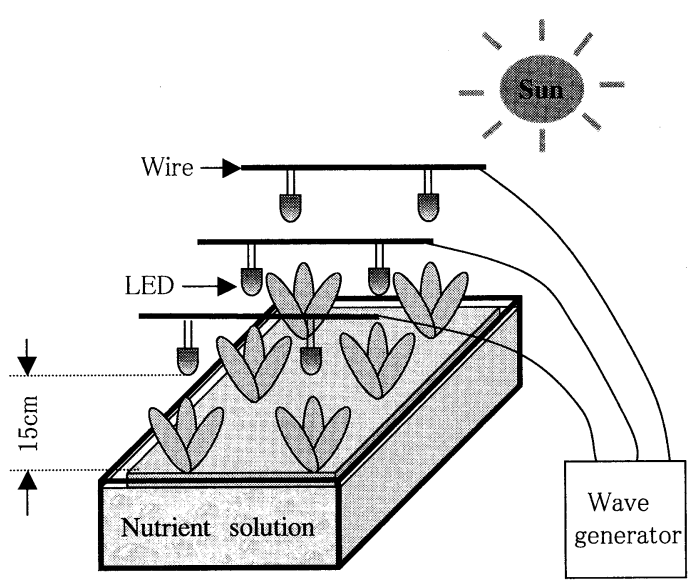

Fig. 1 Light stimulation system
までの距離は照射開始時に約 $5 \mathrm{~cm}$ になるようにした。 なお, 収穫時には植物体の背丈が LED の位置とほほ同 じになった。 なお，本実験の照射装置は，植物体上部に 小型の LED と細い針金が設置されているだけで，太陽 光の遮光はほとんど無く, これによる生育への影響は無 いと考えられた。

\section{3. 生㕕調査}

播種後 65 日目に各試験区 $(24$ 試験区 $\times 2$ 反復 $=48$ 試 験区)それぞれ 6 株のうち, 平均的な生育を示した 2 株 を採って可食部生重量をそれぞれ測定した。対象区も同 様である。

\section{4. 汁液中の無機成分分析}

各試験区から最も平均的な生育をしている 1 株を選び, 可食部生重量の 19 倍量の蒸留水を加えてミキサー(ファ イバーミキサーMX-X42：松下電器産業株式会社)で約 1 分間破砕した。この液をろ過 ( No. $5 \mathrm{~A}$ ： ADVANTEC) 後, 遠心分離 $(10450 \times \mathrm{g}, 5 \mathrm{~min})$ し, 上澄 み液を分析試料とした. $\mathrm{NO}_{3}-\mathrm{N}$ はリフレクトクァント 試験紙を用いて簡易比色計(RQ-Flex：MERCK 社)で 測定し，P は硫酸モリブデン法で ${ }^{12)}, \mathrm{K}, \mathrm{Ca}$ および $\mathrm{Mg}$ は原子吸光光度計 ${ }^{13)}$ で測定した。

\section{結 果}

\section{1. 可食部生重量}

可食部生重量は，培養液中の硝酸態窒素濃度に対応し て変化した。すなわち, 標準濃度区で最も生育が良好 (平均 $71.2 \mathrm{~g}$ ) で, 高濃度区 (平均 $52.6 \mathrm{~g}$ ) と低濃度区 (平 均 $61.8 \mathrm{~g}$ ) では有意に小さかった(Table 2, Table 3). これを対象区の無照射区(Table 2 最下段)と比較すると, 窒素標準濃度区 $(71.2 \mathrm{~g})$ と高濃度区 $(52.6 \mathrm{~g})$ では, 光照 射によってかえって生育量が低下する傾向があるが, 窒 素低濃度区では $61.8 \mathrm{~g}$ を示し, 光照射によって生育が 旺盛になったことが司える, そこで, 硝酸態公素低濃度 区 $(8$ 試験区 $\times 2$ 反復 $=16$ 試験区 $)$ だけに着目して統計処 理を行なうと, Fig. 3 の通りとなり, 可食部生重量は光 照射に大きく影響されていることが分かる.すなわち, 可食部生重量は光照射によって増大するが, とくに 20 $\mathrm{Hz}$ 抢よび $50 \mathrm{~Hz}$ の低い周波数の光照射の場合にそれぞ れ $65.1 \mathrm{~g}, 60.5 \mathrm{~g}$ となって, 効果は明瞭 $(\mathrm{P}=0.02)$ であ るといえた(Fig. 2).

同様に, 硝酸態窒素低濃度区 $(8$ 試験区 $\times 2$ 反復 $=16$ 試験区)に限ってみると光色の違いによる影響も明瞭 $(\mathrm{P}=0.02)$ で, 赤色光区では平均 $59.9 \mathrm{~g}$ であったのに対 して, 黄色光区では平均 $63.7 \mathrm{~g}$ と, より大きかったこ 
Table 2 Effects of $\mathrm{NO}_{3}-\mathrm{N}$ concentration, light color and light frequency on fresh weight and $\mathrm{NO}_{3}-\mathrm{N}$ content of lettuce sap

\begin{tabular}{|c|c|c|c|c|}
\hline \multicolumn{3}{|c|}{ Experimetnal criteria } & \multirow{2}{*}{$\begin{array}{l}\text { Fresh } \\
\text { weight } \\
\text { (g) }\end{array}$} & \multirow{2}{*}{$\begin{array}{c}\begin{array}{c}\text { Inorganic } \\
\text { content }(\mathrm{ppm})\end{array} \\
\mathrm{NO}_{3}-\mathrm{N} \\
\end{array}$} \\
\hline $\begin{array}{c}\mathrm{NO}_{3}-\mathrm{N} \\
\text { concentration }\end{array}$ & Light color & $\begin{array}{l}\text { Light } \\
\text { frequency }\end{array}$ & & \\
\hline \multirow{8}{*}{ High } & \multirow{4}{*}{ Red } & $20 \mathrm{~Hz}$ & 54.1 & 633 \\
\hline & & $50 \mathrm{~Hz}$ & 49.0 & 497 \\
\hline & & $2500 \mathrm{~Hz}$ & 51.9 & 520 \\
\hline & & Continuous & 39.0 & 339 \\
\hline & \multirow{4}{*}{ Yellow } & $20 \mathrm{~Hz}$ & 47.7 & 791 \\
\hline & & $50 \mathrm{~Hz}$ & 59.1 & 452 \\
\hline & & $2500 \mathrm{~Hz}$ & 49.9 & 520 \\
\hline & & Continuous & 69.9 & 249 \\
\hline & Ave. & & 52.6 & 500 \\
\hline \multirow{8}{*}{ Standard } & \multirow{4}{*}{ Red } & $20 \mathrm{~Hz}$ & 79.4 & 520 \\
\hline & & $50 \mathrm{~Hz}$ & 71.9 & 610 \\
\hline & & $2500 \mathrm{~Hz}$ & 63.2 & 384 \\
\hline & & Continuous & 78.1 & 249 \\
\hline & \multirow{4}{*}{ Yellow } & $20 \mathrm{~Hz}$ & 41.4 & 362 \\
\hline & & $50 \mathrm{~Hz}$ & 83.8 & 407 \\
\hline & & $2500 \mathrm{~Hz}$ & 71.0 & 362 \\
\hline & & Continuous & 80.9 & 316 \\
\hline & Ave. & & 71.2 & 401 \\
\hline \multirow{8}{*}{ Low } & \multirow{4}{*}{ Red } & $20 \mathrm{~Hz}$ & 62.3 & 339 \\
\hline & & $50 \mathrm{~Hz}$ & 63.1 & 136 \\
\hline & & $2500 \mathrm{~Hz}$ & 58.0 & 90 \\
\hline & & Continuous & 56.2 & 316 \\
\hline & \multirow{4}{*}{ Yellow } & $20 \mathrm{~Hz}$ & 67.9 & 271 \\
\hline & & $50 \mathrm{~Hz}$ & 65.2 & 384 \\
\hline & & $2500 \mathrm{~Hz}$ & 63.0 & 158 \\
\hline & & Continuous & 58.7 & 158 \\
\hline & \multicolumn{2}{|l|}{ Ave. } & 61.8 & 232 \\
\hline High & \multirow{3}{*}{\multicolumn{2}{|c|}{ (none) Control }} & $\overline{59.6}$ & 520 \\
\hline Standard & & & 88.4 & 407 \\
\hline \multirow[t]{2}{*}{ Low } & & & 51.4 & 181 \\
\hline & Ave. & & 66.5 & 369 \\
\hline
\end{tabular}

Table 3 Analyses of variance in respect of $\mathrm{NO}_{3}-\mathrm{N}$ concentration, light color and light frequency on fresh weight of lettuce

\begin{tabular}{llcrrrc}
\hline \hline & \multicolumn{1}{c}{ Source of variation } & Sum of squares & $\mathrm{v}$ & Mean square & F-value & Probability \\
\hline $\mathrm{A}$ & $\mathrm{NO}_{3}-\mathrm{N}$ concentration & 1389.47 & 2 & 694.74 & 6.15 & 0.04 \\
$\mathrm{~B}$ & Light color & 43.47 & 1 & 43.47 & 0.39 & 0.56 \\
$\mathrm{C}$ & Light frequency & 148.29 & 2 & 74.14 & 0.66 & 0.55 \\
$\mathrm{AB}$ & $\mathrm{NO}_{3}-\mathrm{N}$ concentration $\times$ Light color & 185.26 & 3 & 61.75 & 0.55 & 0.67 \\
$\mathrm{AC}$ & Light color $\times$ Light frequency & 404.52 & 6 & 67.42 & 0.60 & 0.73 \\
$\mathrm{BC}$ & $\mathrm{NO}_{3}-\mathrm{N}$ concentration $\times$ Light frequency & 542.09 & 3 & 180.70 & 1.60 & 0.29 \\
Error & Within treatments & 677.70 & 6 & 112.95 & & \\
\hline Total & & 3390.80 & 23 & & & \\
\hline
\end{tabular}




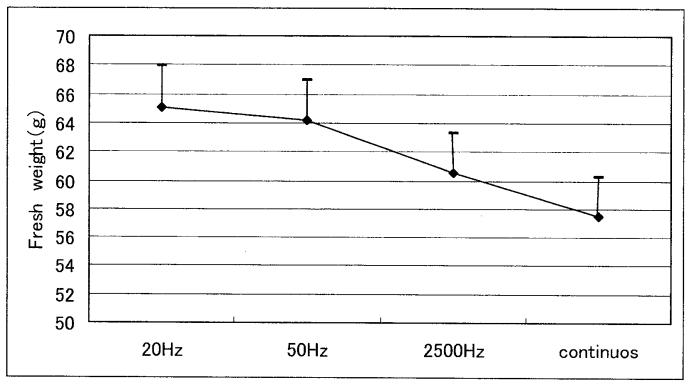

Fig. 2 Effect of LED-light stimulation at various frequency on fresh weight of lettuce in lower $\mathrm{NO}_{3}-\mathrm{N}$ nutrient solution

( : $95 \%$ confidence interval)

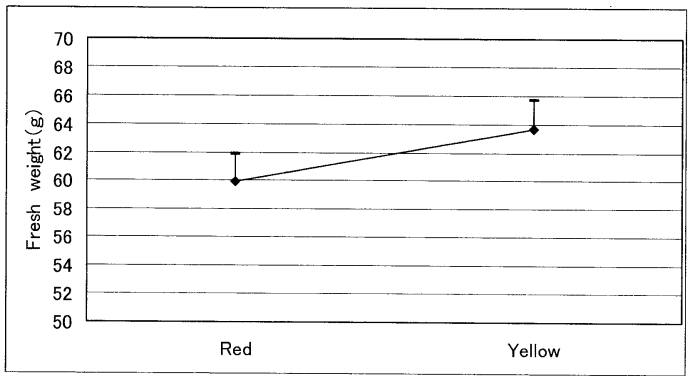

$95 \%$ confidence interval)

\begin{tabular}{llccccc}
\hline \hline & Source of variation & Sum of squares & v & Mean square & F-value & Probability \\
\hline A & Light color & 28.88 & 1 & 28.88 & 18.71 & 0.02 \\
B $\quad$ Light frequency & 74.05 & 3 & 24.68 & 15.99 & 0.02 \\
Error Within treatments & 4.63 & 3 & 1.54 & & \\
\hline Total & 107.56 & 7 & & & \\
\hline
\end{tabular}

Fig. 3 Analyses of variance in respect of light color and light frequency on fresh weight of lettuce consisting of lower $\mathrm{NO}_{3}-\mathrm{N}$ nutrient solution

とが分かる (Fig. 3).

\section{2. 汁液中の無機成分濃度}

汁液中の $\mathrm{NO}_{3}-\mathrm{N}$ 濃度を Table 2 に, 分散分析表を Table 4 に示す。これによると，培養液中の硝酸態窒素 濃度の違いに対応して，レタスの汁液中の $\mathrm{NO}_{3}-\mathrm{N}$ 濃度
が変化し, 硝酸態窒素高濃度区で平均 $500 \mathrm{ppm}$ と最も 高く, 続いて標準濃度区で平均 $401 \mathrm{ppm}$, 低濃度区で平 均 $232 \mathrm{ppm}$ と有意 $(\mathrm{P}=0.00)$ に低かった。

また，統計的に有意ではなかったが，硝酸態窒素低濃 度区で, 点滅周波数が $20 \mathrm{~Hz}$ の時には, 汁液中の $\mathrm{NO}_{3}$ $-\mathrm{N}$ 濃度が平均 $305 \mathrm{ppm}$ を示し, 無照射区の $181 \mathrm{ppm}$ の みならず他の窒素低濃度区の全平均值である $207 \mathrm{ppm}$ よりも高く回復しているように見うけられた。

なお, 汁液中の $\mathrm{P}$ 濃度, $\mathrm{K}$ 濃度, $\mathrm{Ca}$ 濃度, $\mathrm{Mg}$ 濃度 はどれも試験要因の影響を受けず，全試験区の平均值は それぞれ 188 ppm, 4711 ppm, 1019 ppm, 200 ppm であっ た.

\section{考察}

\section{1. 生育結果}

これまでに, ストロボ光による光照射で, 生育に差が 見られたが6 8), LED 光でも光色と光の点滅周波数に よって可食部生重量が影響を受けた。とくに，硝酸態窒 素低濃度区では，無照射区よりも光照射区の方が大きく， 中でも低い周波数である $20 \mathrm{~Hz}$ の光照射をした時が最 もその効果は大きかった. また, 光色についてみると, 赤色光を照射した場合よりも, 黄色光を照射した場合の ほうが可食部生重量が大きかった。クロロフィルの極大 吸収波長ではない黄色の弱い LED 光で, しかも低い周 波数の点滅光が, 光エネルギーとして直接的に光合成量 を増加させているとは考えにくいので，筆者らは光が刺 激となって可食部生重量が増大したものと考えている. 今後, この現象についてさらに検討する予定である.

\section{2. 汁液中の無機成分濃度}

すでにストロボ光照射により $\mathrm{P}, \mathrm{Ca}, \mathrm{Mg}$ 濃度が増加 するとの報告 ${ }^{8)}$ があるが, 本実験に抢いては LED 光の 照射が $\mathrm{NO}_{3}-\mathrm{N}$ 濃度に影響を及ぼしていることが示され た. 光照射をした場合に，その周波数が低い $20 \mathrm{~Hz}$ 区 のレタス汁液中の $\mathrm{NO}_{3}-\mathrm{N}$ 濃度が高い傾向があったとい

Table 4 Analyses of variance in respect of $\mathrm{NO}_{3}-\mathrm{N}$ concentration, light color and light frequency on $\mathrm{NO}_{3}-\mathrm{N}$ content of lettuce sap.

\begin{tabular}{|c|c|c|c|c|c|c|}
\hline & Source of variation & Sum of squares & $\mathrm{v}$ & Mean square & F-value & Probability \\
\hline A & $\mathrm{NO}_{3}-\mathrm{N}$ concentration & 295335.25 & 2 & 147667.63 & 15.20 & 0.00 \\
\hline $\mathrm{B}$ & Light color & 1717.04 & 1 & 1717.04 & 0.18 & 0.68 \\
\hline $\mathrm{C}$ & Light frequency & 11843.58 & 2 & 5921.79 & 0.61 & 0.57 \\
\hline $\mathrm{AB}$ & $\mathrm{NO}_{3}-\mathrm{N}$ concentration $\times$ Light color & 155507.46 & 3 & 51835.82 & 5.34 & 0.02 \\
\hline $\mathrm{AC}$ & $\mathrm{NO}_{3}-\mathrm{N}$ concentration $\times$ Light frequency & 112919. 42 & 6 & 18819.90 & 1.94 & 0.18 \\
\hline Error & Within treatments & 87414.88 & 9 & 9712.76 & & \\
\hline Total & & 664737.63 & 23 & & & \\
\hline
\end{tabular}


う事実と, 培養液中の硝酸態窒素濃度が低い場合に, 低 い周波数の光照射で，レタスの生育が良好であったとい う両者の相関は，レタスの生育促進の現象を考えるうえ で重要である。

\section{3. 今後の展望}

今後, 光刺激と光合成との関連性や日射量との関連性 を検討することにより，低い周波数の光を与えることで， 植物の生育を制御することができると考えている，筆者 らは,これにより収量増大や肥料の過剰施肥による環境 悪化の問題を解決する糸口が見出せたものと考えている.

\section{まとめ}

本研究では養液栽培法を用いて, レタスに特定周波数 の LED 光を与えた時の可食部生重量, 汁液中の無機成 分濃度について測定した。その結果, 培養液中の硝酸態 窒素濃度を通常の場合よりも 3 割減の濃度で栽培してい るレタスに, $20 \mathrm{~Hz}$ や $50 \mathrm{~Hz}$ の低い周波数の黄色または 赤色の光刺激を与えた時に, 可食部生重量が大きい傾向 があった.クロロフィルの極大吸収波長である $660 \mathrm{~nm}$ 付近の赤色光以外に, クロロフィルにはあまり吸収され ない $570 \mathrm{~nm}$ 付近の黄色光を照射した場合にもこの効果 が見られた. また, 赤色光, 黄色光ともに低周波の光刺 激を与えた場合に汁液中の $\mathrm{NO}_{3}-\mathrm{N}$ 濃度が高かった。こ れらの事実から，われわれは照射した光が刺激となって， レタスの養分吸収や生育に影響を与えたものと考える.

\section{謝辞}

本研究を実施するに当たり, 栽培管理と化学分析等で 協力いただいた栗田真吏氏, 木村豊氏に深く御礼申し上 げる.

\section{引用文献}

1）羽生広道，庄子和博：夜間補光の光質制御による ホウレンソウの生育改善一青や赤の短時間補光に より起こる生長促進現象一, 農業環境工学 4 学会 2002 年合同大会, pp. 357 (2002)

2）小島孝之, 山崎明, 中原光久, 中野智子： LED 補光によるトマト接ぎ木苗の養生効果, 日 本植物工場学会平成 10 年度大会学術講演要旨集, pp. 24-25(1998)

3）森 康裕, 高辻正基：レーザー光によるサラダナ 栽培実験, 植物工場学会誌 13(1)：7-12(2001)

4）高橋直樹, 平間淳司, 宮本紀男, 堀岡雅清, 弘田 憲史：茸(なめこ)における光刺激と生体電位反応 (第 1 報)一刺激波長と生体電位との関係一, 植物 工場学会誌 11 (3) : 209-213(1999)

5）山崎 文，土屋広司，宮島博文，本間高宜，管博 文：半導体レーザー光がサラダナ生育に及ぼす影 響，植物工場学会誌 12(2)：93-98(2000)

6) 浅井 司, 齋藤真琴, 中林和重：ストロボ光照射 とUV照射および培養液へのサンゴ砂の添加が サラダナの収量や品質におよぼす影響，農業環境 工学関連 4 学会 2001 年合同大会, pp. 245(2001)

7）栗田真吏, 浅井 司, 中林和重, 船木正人：養液 栽培サラダ菜への光照射と培養液へのサンゴ砂添 加が葉面電位変化と植物体中無機成分に及ぼす影 響, 農業環境工学関連 4 学会 2001 年合同大会講 演要旨, pp. 248(2001)

8）中林和重, 浅井司：ストロボ光やUV光によ る補光抢よび培養液へのサンゴ砂の添加がレタス の収量や品質に及ぼす影響, 植物工場学会誌 13 (3) : 183-191 (2001)

9）中里博明, 平栗 昇ほか：実験計画法テキスト, 日本技連，pp. 125-149(1991)

10）奥野忠一, 芳賀敏郎：実験計画法, 培風館, pp. 94-130 (1969)

11）社団法人日本施設園芸協会：最新養液栽培の手引 き，誠文堂進光社，pp. 140-156(1996)

12）作物分析法委員会：栄養診断のための栽培植物測 定法，養賢堂，pp. 71-72(1975)

13）長谷川和雄, 保田敬彦: 原子吸光分析, 講談社, pp. 148-265(1972) 